\title{
Kolaborasi Komunitas Stucash dan Lakoni dalam Penanganan Dampak Sosial-Ekonomi Pandemi COVID-19
}

\author{
Miftah Awalurrizqi ${ }^{1}$, Agresti Retno Sumantiyasmi ${ }^{2}$, Atikah Azzahidah ${ }^{3}$
}

\begin{abstract}
Abstrak
Komunitas Stucash dan Lakoni menjadi aktor penting dalam penanganan pandemi COVID-19 di Yogyakarta karena bersentuhan secara langsung dengan masyarakat dan juga telah akrab dengan pemanfaatan teknologi digital. Penelitian ini bertujuan untuk melihat bagaimana kolaborasi dua komunitas tersebut dalam penanggulangan dampak sosialekonomi akibat pandemi. Komunitas Stucash dan Lakoni dipilih sebagai fokus penelitian karena mereka merupakan representasi dari pergerakan sosial oleh pemuda, mulai dari tahap inisiasi, konsepsi hingga eksekusi. Penelitian ini merupakan jenis penelitian kualitatif-deskriptif dengan teknik pengumpulan data melalui wawancara secara daring terhadap perwakilan dari setiap komunitas, dokumentasi dan observasi pada publikasi serta interaksi dari akun media sosial di tiap komunitas. Hasil dari penelitian menunjukkan bahwa Stucash dan Lakoni mampu membantu kinerja Pemerintah Daerah D.I. Yogyakarta dalam menanggulangi dampak sosial-ekonomi akibat pandemi COVID-19 dengan menggunakan pendekatan partisipatif dimana komunitas sebagai wujud aktor dari masyarakat menjadi inisiator utama sekaligus eksekutor gerakan dengan memanfaatkan teknologi digital yang dalam hal ini yaitu media sosial.
\end{abstract}

Kata Kunci: Kolaborasi, Komunitas Pemuda, Media Baru, Pandemi COVID-19

\begin{abstract}
The Stucash and Lakoni communities are important actors in handling the COVID-19 pandemic in Yogyakarta because they have direct contact with the community and familiar with the utilization of digital technology. This study aims to see how the collaboration of the two communities in dealing with the socio-economic impacts of the pandemic is. The Stucash and Lakoni communities were chosen as the research focus because they represent the social movements of youth from initiation, conception to execution stages. This research is a descriptive-qualitative type with data collection techniques through online interviews to representatives from each community, documentation and observation on publications and interactions in social media accounts of each community. The results of the study show that Stucash and Lakoni are able to help the performance of the local government of D.I. Yogyakarta in overcoming the socio-economic impacts of the COVID-19 pandemic by using a participatory approach in which the community as an actor from society becomes the main initiator and executor of the movement by utilizing digital technology, which in this context is social media.
\end{abstract}

Keywords: Collaboration, COVID-19 Pandemic, New Media, Youth Communities

\section{Pendahuluan}

Pemerintah Provinsi Daerah Istimewa (D.I) Yogyakarta telah melakukan berbagai upaya untuk menangani pandemi COVID-19 di Yogyakarta, misalnya dengan menyediakan sarana kesehatan, pemberdayaan Usaha Mikro Kecil Menengah (UMKM), layanan kesehatan melalui posko penanganan virus, patroli di tempat keramaian dan yang rentan terjadinya Tindakan kriminalitas. Dalam menghadapi hal tersebut tentu dibutuhkan kerjasama berbagai pihak. Penanganan COVID-19 tidak hanya dilakukan secara vertikal atau top-down (antara pemerintah dengan komponen di bawahnya), melainkan juga secara partisipatif (melibatkan masyarakat). Sejalan dengan itu, pemuda yang merupakan salah satu elemen dalam masyarakat juga telah ikut berperan dalam penanganan dampak dari adanya pandemi. Dalam kasus ini, pemuda memiliki caranya sendiri dalam membantu pemerintah dalam upaya penanggulangan dampak sosial-ekonomi akibat pandemi COVID-19. Dalam melakukan aksinya, pemuda menggunakan media sosial

\footnotetext{
${ }^{1}$ Fakultas Ilmu Sosial dan Ilmu Politik, Universitas Gadjah Mada (email korespondensi: awalurrizqi17@gmail.com)

${ }^{2}$ Fakultas Ilmu Sosial dan Ilmu Politik, Universitas Gadjah Mada (email: agretirtns@gmail.com)

${ }^{3}$ Fakultas Ilmu Sosial dan Ilmu Politik, Universitas Gadjah Mada (email: atikaaz07@gmail.com)
} 
sebagai instrumen penggerak sumber dayanya. Hal tersebut lekat dengan karakter pemuda sebagai digital natives dan net generation. Sehingga, gerakan sosial dan penggunaan media sosial yang dilakukan pemuda sebagai bagian dari masyarakat di masa pandemi ini akan membawa karakteristik tertentu dan menjadi hal yang menarik untuk diteliti lebih lanjut.

Lebih lanjut lagi, D.I Yogyakarta merupakan provinsi yang dinamis, dikenal sebagai kota pelajar dan pariwisata. Pembangunan sekolah dan universitas di Yogyakarta telah terjadi sejak tahun 1950-an dan berdampak pada terbentuknya Yogyakarta sebagai kota pendidikan yang juga lekat dengan aktivisme pemuda (Soemardjan, 2009: 38). Kondisi yang demikian pada gilirannya juga mengantarkan pada kondisi demografis yang semakin kompleks karena pelajar di Yogyakarta datang dari pelbagai penjuru daerah. Sehingga menjadi wajar apabila kemudian terjadi lonjakan jumlah pemuda yang ada di D.I Yogyakarta ini mengingat banyaknya pendatang yang bertujuan untuk belajar.

Pada sisi yang lain, pemuda di D.I Yogyakarta juga berperan dalam menginisiasi berbagai gerakan sosial di masyarakat, terutama di tengah pandemi ini. Keterlibatan aktif dari pemuda ini sangat diharapkan untuk dapat mampu menghadirkan harapan baru bagi kalangan masyarakat yang paling rentan terdampak oleh COVID-19. Adapun pemuda yang dimaksud di sini ialah mereka yang menjadi bagian dari digital natives dengan karakteristik fasih dalam menggunakan teknologi, terutama internet. Terlahir sebagai digital natives, pemuda tentu memiliki pendekatan yang unik dalam mengambil peran di masyarakat. Selain itu, keterlibatan pemuda dalam penanganan COVID-19 juga menarik untuk diteliti karena mereka merupakan pemimpin masa depan bangsa sehingga pemuda harus dibekali dengan kapasitas yang mumpuni, tidak hanya leadership-skill tetapi juga sensitivitas empati. Dengan demikian, penelitian ini bertujuan untuk mendeskripsikan partisipasi dan kolaborasi pemuda yang tergabung pada komunitas Stucash dan Lakoni dalam upaya penanganan pandemi COVID-19 di Yogyakarta.

\section{Kerangka Teori}

Komunitas Pemuda dalam Penanganan Pandemi

Pandemi COVID-19 diidentifikasi sebagai bencana dengan melihat ketidakmampuan masyarakat Indonesia dalam menghadapinya, bahkan juga di seluruh dunia. Hal tersebut selaras dengan konsep bencana dari Ariyabandu dalam Hossain (2013:60) yang menyatakan bahwa bencana merupakan kombinasi dari bahaya dan kerentanan. Menurutnya, kombinasi tersebut terletak pada adanya bahaya yang dianggap sebagai potensi terjadinya fenomena yang mengancam masyarakat. Pada saat yang sama, masyarakat juga menjadi sedemikian rentan terdampak karena kapasitasnya menanggulangi dampak dari bahaya tersebut begitu lemah. Bencana juga diartikan sebagai dampak fisik dan sosial yang membuat sebagian atau seluruh fungsi esensial pada masyarakat menjadi terganggu (Fritz dalam Schwartz dan Yen, 2016: 126).

Tidak hanya pada tingginya angka jumlah korban, dampak COVID-19 juga merambah pada aspek ekonomi seperti meningkatkan jumlah pengangguran, perubahan lanskap pasar tenaga kerja, menurunnya pertumbuhan ekonomi, dan dampak-dampak lain yang mengancam masyarakat. Hal tersebut menjadi bukti nyata ketidakmampuan pemerintah dan masyarakat dalam menghadapi wabah penyakit ini.

Pandemi sebagai bencana non-alam tentu membutuhkan penanganan yang berbeda dengan bencana alam. Penanganan pandemi akan sangat bergantung pada penyediaan fasilitas kesehatan negara yang terkoordinasi dengan baik. Namun, pada kenyataannya perencanaan secara state-centered belum mampu menangani pandemi secara optimal. Oleh sebab itu, dibutuhkan respon terhadap pandemi dengan mengolaborasikan kebijakan pusat dan partisipasi aktif bersama masyarakat. Bentuk dari kolaborasi ini dapat bersifat formal maupun non-formal. Dalam manajemen kolaborasi, salah satu unsur masyarakat yang dibutuhkan untuk membersamai upaya pemerintah adalah partisipasi komunitas yang dalam hal ini adalah pemuda. Partisipasi didefinisikan sebagai aksi kolektif oleh berbagai strata individu atau kelompok. Inti partisipasi komunitas adalah pelaksanaan 'suara dan pilihan' komunitas dan pengembangan kapasitas manusia, organisasi, dan manajemen untuk memecahkan masalah yang muncul dalam rangka mempertahankan perbaikan yang dilakukan dari waktu ke waktu (Sastry, 2001 dalam Hossain 2013:161). Komunitas pemuda dianggap yang paling paham mengenai kondisi yang ada di sekitarnya, maka mereka bisa menginisiasi gagasan yang tepat 
Miftah Awalurrizqi, Agresti Retno Sumantiyasmi, Atikah Azzahidah - Kolaborasi Komunitas Stucash dan Lakoni dalam Penanganan Dampak Sosial-Ekonomi Pandemi COVID-19

untuk mengatasi berbagai batasan struktural yang mungkin ada di masyarakat. Partisipasi komunitas pemuda juga membuka akses yang lebih besar untuk kolaborasi dengan pihak lain dalam upaya melakukan tanggapan kolektif. Kolaborasi dengan komunitas akan lebih berpotensi untuk menemukan solusi inovatif yang sesuai dengan kebutuhan populasi (Marston et al., 2020: 1676). Oleh karena itu, adanya kolaborasi dapat memungkinkan pemahaman yang lebih baik mengenai kondisi sekitar, kerentanan, dan kapasitas masyarakat itu sendiri sehingga dapat tercipta alokasi sumber daya yang lebih baik.

Peran komunitas dirasa cukup sentral karena komunitas adalah yang paling mengerti kondisi di sekitarnya, sehingga komunitas menjadi garda terdepan dalam upaya penanggulangan bencana. Hal tersebut juga sejalan dengan pendapatnya Smith dan Wandel (2006: 286) yang menyatakan bahwa peran komunitas adalah pada tahap identifikasi risiko bencana dan kerentanan. Selain itu, terdapat pula beberapa model dari berbagai penelitian terdahulu yang telah mengembangkan konsep keterlibatan komunitas dalam manajemen bencana. Dalam model ini, keterlibatan stakeholder dan komunitas difokuskan pada peningkatan "kapasitas adaptif" yang merujuk pada kemampuan adaptasi dan ketangguhan masyarakat untuk menyelesaikan masalah (Patterson et al., 2010:131). Lebih lanjut lagi, terdapat juga model integrating community-based disaster management (ICBDM) dari Chen \& Chan dalam Patterson et al. (2010: 132) yang menjelaskan peran komunitas dalam persepsi risiko dan kesiapsiagaan bencana sebagaimana terlihat pada gambar 1 berikut ini:

Berdasarkan gambar tersebut, Chen \& Chan menggarisbawahi urgensi anggota komunitas dalam mendefinisikan tujuan dan strategi dalam mitigasi bencana. Dengan diawali dari tahap "initiation," komunitas kemudian mengembangkan penilaian mereka melalui pengalaman sebelumnya dalam menghadapi bencana (Patterson, 2010: 133). Selanjutnya, komunitas mengidentifikasi masalah dan mengembangkan solusinya seiring dengan peningkatan pemahaman mereka terkait upaya penanganan suatu bencana. Tidak hanya itu, Chen \& Chan juga menekankan bahwa jika komunitas dapat memperkuat kohesi sosial sehingga dapat memainkan peran kunci dalam pelaksanaan program kesiapsiagaan bencana.

\section{Gambar 1 \\ Model Integrating Community-Based Disaster Management}

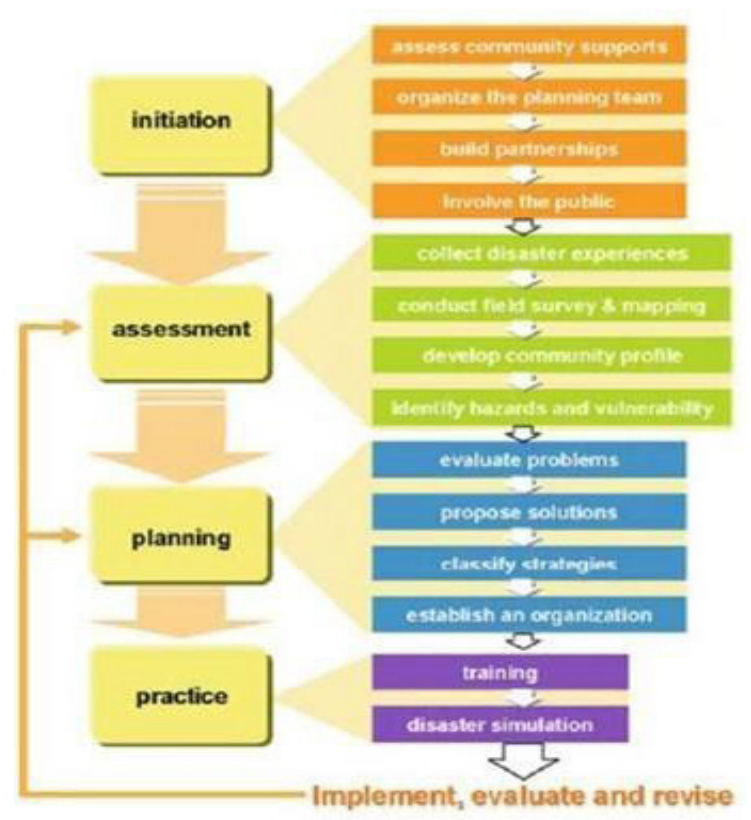

Sumber: Chen \& Chan dalam Patterson et al. (2010: 132)

\section{Gerakan Sosial}

Merujuk pada Giddens (1993) dalam Suharko (2006:3) mendefinisikan gerakan sosial sebagai upaya untuk mencapai kepentingan atau tujuan bersama melalui tindakan kolektif (collective action) yang dilakukan di luar ranah institusi yang mapan. Konsep gerakan sosial tersebut melihat bahwa gerakan sosial sebagai tindakan secara bersama-sama yang dilakukan oleh banyak orang yang tidak terikat pada institusi tertentu, seperti pemerintahan dan partai. Dalam arti yang lain, gerakan sosial merupakan tindakan kolektif yang dilakukan oleh masyarakat sipil untuk mencapai tujuan bersama. Konsep tersebut relevan dengan komunitas yang dipelopori oleh pemuda yang mana mereka adalah komunitas yang independen. Komunitas pemuda tidak terikat atau berafiliasi dengan lembaga pemerintah maupun yang lainnya. Komunitas pemuda tersebut memiliki sumber daya berupa anggota dan partisipan-partisipan lain. Adanya dampak sosial-ekonomi akibat pandemi COVID-19 menjadi momentum untuk kedua komunitas tersebut bergerak secara kolektif. Gerakan tersebut termanifestasi dari pengorganisasian 
anggota dan partisipan lainnya dengan tujuan untuk menanggulangi dampak sosial-ekonomi akibat pandemi.

Sebagaimana juga dikatakan oleh Locher (2002) dalam Sukmana (2016:14) mengatakan bahwa gerakan sosial terbentuk akibat adanya pengorganisasian yang dilakukan oleh sekelompok orang yang bertujuan untuk mendorong atau menghambat suatu perubahan sosial. Konsep tersebut menggambarkan bahwa gerakan sosial terjadi ketika sekelompok orang mengorganisir diri untuk mendorong atau menolak suatu perubahan sosial guna membuat kondisi di sekitarnya tetap stabil atau bisa juga jadi lebih baik. Kaitannya dengan komunitas pemuda, mereka sebagai komunitas mengorganisasikan anggota dan partisipannya untuk mendorong perubahan sosial. Perubahan sosial yang dimaksud adalah merubah adanya dampak sosial-ekonomi akibat pandemi menuju terciptanya kondisi yang lebih baik di masyarakat.

Terlebih lagi, Locher (2002) dalam Sukmana (2006:11-13) juga mengemukakan bahwa terdapat tiga aspek untuk membedakan gerakan sosial dengan tindakan-tindakan kolektif lainnya, antara lain crowd (kerumunan), riot (kerusuhan), dan rebel (pembangkangan atau penolakan). Aspek pertama adalah aspek terorganisasi (organized) yang menekankan bahwa gerakan sosial pada dasarnya adalah tindakan kolektif yang sudah lebih terorganisir, berbeda dengan tindakan kolektif lainnya yang sifatnya dadakan dan tidak teratur. Selanjutnya, aspek pertimbangan (deliberate) melihat bahwa gerakan sosial dilakukan dengan penuh pertimbangan dalam memutuskan keterlibatan pada suatu aksi. Terakhir, aspek daya tahan (endurance) muncul sebagai efek dari adanya aspek terorganisir dan aspek pertimbangan. Maka, gerakan sosial dianggap dapat berlangsung dalam waktu yang lama sejalan dengan isu yang luas dan berkelanjutan. Untuk mendukung hal tersebut, maka gerakan sosial perlu memiliki daya tahan (endure).

\section{Pemuda, Kolaborasi, dan Pemanfaatan Media Digital}

Merujuk pada sejarah, pemuda yang tergolong sebagai kaum intelektual memiliki potensi untuk melakukan perubahan dan gerakan dalam masyarakat. Sebagaimana Edward Shill (1960) menyatakan bahwa ada lima fungsi pemuda sebagai kaum intelektual, yakni mencipta dan menyebar kebudayaan tinggi, menyediakan bagan-bagan nasional dan antar bangsa, membina keberdayaan dan kebersamaan, memengaruhi perubahan sosial dan memainkan peran politik. Dalam literatur yang lain, Naff dan White (2012) dalam Widhyharto (2014) juga menganalisis diskursus mengenai pemuda ke dalam tiga perspektif, yaitu pemuda sebagai generasi, pemuda sebagai transisi, dan pemuda sebagai pencipta dan konsumen budaya. Sebagai sebuah generasi, pemuda akan mengingatkan kita pada konstruksi mengenai pemuda yang berbeda dari generasi ke generasi. Setiap konteks ruang dan waktu akan berdampak pada bagaimana konstruksi mengenai pemuda itu dapat terbentuk. Konstruksi mengenai pemuda pada saat kemerdekaan dan saat ini akan sangat berbeda, meski pada tataran nilai dasarnya masih sama. Sementara itu, pemuda sebagai transisi melihat pemuda melalui pendekatan deterministik yang meyakini bahwa pemuda mengalami tahapan kehidupan yang bersifat tetap dan universal (Sutopo, 2014). Hal ini berkaitan dengan fungsi dan peran pemuda yang akan memunculkan keseimbangan dalam masyarakat.

Ketika pemuda masuk dalam arena sosial masyarakat yang lebih luas, kaum muda dihadapkan pada struktur eksternalitas yang lebih masif, melintasi batas negara, dan sekatsekat ekonomi, politik, dan budaya yang menjadi semakin menipis (Giddens dalam Ritzer, 2003). Hal tersebut kemudian menempatkan kaum muda dalam posisi yang ambigu, di satu sisi mereka adalah produsen sekaligus konsumen utama, namun di sisi lain mereka adalah kelas proletariat baru globalisasi sebagaimana dijelaskan oleh Bayat dan Herrera (2011) dalam Azca, Widhyharto, Sutopo, (2014). Salah satu faktor yang mempercepat dan memiliki andil dalam kehidupan pemuda saat ini adalah media baru. Karakter media baru yang bebas memberikan ruang bagi pemuda untuk menjalankan aktivitas mereka sebagai produsen sekaligus konsumen.

Media sosial sebagai bentuk media baru menjadi unsur penting bagi pemuda sebagai digital native dalam upaya penanganan pandemi COVID-19. Dalam menghadapi COVID-19, pemuda dituntut untuk mampu menyesuaikan diri dan menjalankan perannya. Aktivitas 
keseharian pemuda juga seringkali tidak dapat dilepaskan dari media baru tersebut. Sebagaimana hasil penelitian yang dilakukan oleh YouSure (2013) menyatakan di level lokal mengenai aktivisme pemuda Yogyakarta di media baru, tercatat bahwa sebanyak $75,46 \%$ atau 203 responden memilih pernah merespons permasalahan publik melalui media daring, sedangkan hanya sekitar $23,79 \%$ yang mengaku belum pernah merespons permasalahan publik di media daring. Hal ini menunjukkan bahwa bagi kaum muda, kehidupan personal dan sosial di dunia nyata dan dunia maya sudah saling terhubung dan terintegrasi.

Pemuda memiliki keterbukaan digital yang memungkinkan terjadinya perubahan sosial dengan cara baru. Praktik kaum muda mengakses media baru sebagai aktivitas yang paling banyak dilakukan dalam mengisi waktu luang berbanding lurus dengan pola aktivitas kaum muda sebagai digital natives dan peningkatan sumber daya akses yang tersedia (Widhyharto dkk, 2014). Dalam konteks ini, pemuda dapat digolongkan dalam Gen $C$ yang didasarkan pada segmentasi attitude dan mindset yang berpusat pada empat aspek yaitu creation, curation, connection, dan community (Sugihartati, 2014). Dalam literatur yang lain, Tapscott (2009) menyatakan bahwa terdapat delapan aspek yang menyamakan pemuda sebagai "net generation" yaitu freedom, customization, scrutiny, integrity, collaboration, entertainment, speed, dan innovation. Dari delapan aspek tersebut, aspek kolaborasi menjadi landasan mengenai bagaimana karakter pemuda dalam penanggulangan pandemi COVID-19 melalui media baru. Kolaborasi oleh pemuda bersifat bebas, terkustomisasi, inovatif, dan kritis. Mereka berjejaring menggunakan berbagai media sosial, bahkan mereka menciptakan kolaborasi untuk kepentingan tertentu yang bisa jadi tidak mungkin dilakukan dalam dimensi luring.

Pemanfaatan media digital dalam merespon dampak COVID 19 dapat ditelaah menggunakan teori ketergantungan media (media dependency) yang dicetuskan oleh Melvin dan Sandra Ball Rokeach. Teori ini menyatakan bahwa semakin seseorang bergantung pada media, maka media tersebut semakin penting bagi orang tersebut. Teori ini mengonseptualisasi media sebagai sistem informasi utama dan jaringan yang menghubungkan individu-individu dengan masyarakat (Merskin, 1999; Waring, 1996 dalam Cho, 2009). Seiring dengan perkembangan teknologi komunikasi, media yang dimaksud dalam teori ini turut bertransformasi mencakup media baru seperti media sosial. Ketergantungan media baru (new media dependency) merupakan teori yang masih didasarkan pada teori ketergantungan media milik Melvin dan Sandra Ball Rokeach. Teori ini dapat digunakan untuk melihat bagaimana cakupan dan intensitas hubungan yang dibangun orang-orang dengan kehidupan keseharian mereka. Ada dua kondisi yang menjadi faktor pencetus peningkatan ketergantungan pada media. Pertama, jumlah media yang meningkat di masyarakat dan pentingnya fungsi media. Kedua, adanya perubahan sosial dan konflik. Perubahan sosial yang terjadi saat pandemi membuat masyarakat bergantung pada media sebagai sumber informasi dan sarana berkomunikasi.

\section{Metode Penelitian}

Penelitian ini menggunakan pendekatan kualitatif-deskriptif. Menurut Bogdan dan Taylor (1975, dalam Moleong, 2007), penelitian kualitatif adalah prosedur penelitian yang menghasilkan data deskriptif berupa ucapan, tulisan, atau perilaku yang dapat diamati dari subyek penelitian. Penelitian kualitatif bertujuan untuk menghasilkan pemahaman yang menyeluruh dan kontekstual berdasarkan kekayaan data yang rinci dan bernuansa (Mason, 2002). Fokus penelitian ini adalah komunitas pemuda di Yogyakarta yaitu Stucash dan Lakoni. Stucash dan Lakoni dipilih karena berperan dalam pergerakan sosial oleh pemuda mulai dari tahap inisiasi, konsepsi hingga eksekusi. Teknik pengumpulan data dilakukan dengan cara wawancara mendalam dengan dua perwakilan Stucash dan dua perwakilan Lakoni melalui media daring Google Meet dalam waktu masing-masing selama dua jam. Data sekunder dikumpulkan melalui dokumentasi dan observasi daring pada akun media sosial milik Stucash dan Lakoni. Data yang telah terkumpul dianalisis menggunakan teknik analisis data penjelasan terhadap kasus (explanation building).

\section{Hasil \\ Latar Belakang Aksi Komunitas Stucash dan Lakoni \\ Jiwa sosial yang tinggi serta didukung pengalaman dari komunitas Stucash dalam}


membantu masyarakat dalam penanggulangan masalah yang terjadi menjadi latar belakang dari aksi mereka. Aksi yang dijalankan oleh Stucash dan Lakoni ini dilakukan secara sukarela dan berangkat dari keresahan akibat dampak negatif pandemi COVID 19.

"Kami berangkat dari adanya keresahan yang dirasakan oleh anggota kami mengenai kondisi sosial akibat COVID 19. Partisipan yang terlibat dalam aksi ini bersifat sukarela dan memiliki rekam jejak yang sesuai." (Jendra, Wawancara 17 September 2020).

Kedekatan dan kontak langsung kedua komunitas dengan masyarakat yang terdampak COVID-19 juga menguatkan inisiasi untuk berupaya untuk melakukan penanggulangan. Adanya kesadaran sebagai bagian dari masyarakat dan ingin mengubah keadaan jadi lebih baik membuat Stucash dan Lakoni menciptakan kolaborasi yang efektif dalam upaya penanggulangan dampak sosial-ekonomi akibat COVID-19.

Kolaborasi sebagai Cara Pengorganisasian Sumber Daya

Sebagai salah satu bentuk dari gerakan sosial, tentunya Stucash dan Lakoni juga memerlukan sumber daya untuk dapat melaksanakan aksinya. Selain adanya anggota, sumber daya yang dimiliki oleh Stucash datang dari kolaborasi dengan pihak-pihak luar. Stucash bergerak berdasarkan kolaborasi yaitu dengan komunitas pemuda yang lain seperti Lakoni dan pihakpihak terkait yang memiliki misi yang sama dalam penanggulangan dampak sosial-ekonomi akibat COVID-19. Adanya kolaborasi tersebut membentuk jaringan yang kuat sehingga upaya penanggulangan dapat terlaksana dengan lebih optimal.

"Program ini dijalankan melalui kolaborasi dengan komunitas lain yaitu Fakultas Farmasi UGM dan Lakoni. Kerjasama dengan Fakultas Farmasi dijalankan dalam rangka penyaluran APD, dibantu oleh ACT (Aksi Cepat Tanggap). Kolaborasi juga dilakukan melalui Ketua BEM melalui penggalangan dana dan penyebaran informasi." (Jendra, Wawancara 17 September 2020).

Adanya sumber daya berupa anggota dan partisipan dari pihak-pihak lain kemudian diorganisasikan oleh Stucash dan Lakoni dengan cara berkolaborasi. Dengan melakukan kolaborasi, aksi akan semakin optimal guna mencapai tujuan bersama. Kolaborasi Stucash dan Lakoni dengan pihak-pihak lainnya menjadi kekuatan dan kunci utama dalam upaya mereka melakukan penanggulangan. Adanya kolaborasi tersebut menciptakan jaringan pengaman sosial yang cukup baik untuk membantu masyarakat mempertahankan hidupnya di tengah terpaan dan dampak pandemi.

\section{Penggunaan Media Sosial sebagai Instrumen} Pengorganisasaian dan Kolaborasi

Di tengah keterbatasan akibat kondisi pandemi, Stucash dan Lakoni harus menyesuaikan diri dalam menjalankan aksinya. Di tengah kondisi pandemi yang tidak memungkinkan melakukan pertemuan tatap muka langsung, Stucash dan Lakoni menggunakan media sosial sebagai alat atau instrumen alternatif dalam pelaksanaan upaya penanggulangan dampak dari pandemi. Berikut keterangan dari hasil wawancara dengan perwakilan komunitas (wawancara 17 September 2020):

"Sebagian besar persiapan dan mobilisasi kami lakukan melalui internet dan media sosial. Koneksi dan kolaborasi yang kita jalankan cukup membantu sehingga kami tidak merasa bekerja sendirian. Kami juga membuat divisi khusus untuk mencari info terkait kondisi di lapangan."

Stucash dan Lakoni sebagai komunitas pemuda yang termasuk digital native menggunakan media sosial sebagai instrumen utama dalam inisiasi dan eksekusi aksi. Penggunaan media sosial dipilih karena lebih efektif dan efisien untuk menjangkau publik secara lebih luas. Dengan demikian, upaya mereka membantu masyarakat menghadapi dampak pandemi COVID-19 menjadi lebih optimal.

\section{Diskusi}

Komunitas Pemuda dalam Penanganan Pandemi Sri Sultan Hamengku Buwono X selaku Gubernur D.I Yogyakarta secara resmi menyampaikan bahwa COVID-19 sedang terjadi di Yogyakarta dan memulai masa tanggap darurat melalui agenda Sapa Aruh "Pacobaning Gusti Allah Awujud Virus Corona" di Bangsal Kepatihan, Danurejan, Yogyakarta pada 23 Maret 
yang lalu. Hingga saat ini, status tanggap darurat tersebut terus diberlakukan. Status tersebut ditindaklanjuti secara serius oleh Gubernur D.I Yogyakarta dengan dibersamai berbagai kebijakan dan imbauan, baik yang sifatnya pencegahan hingga penanganan.

Langkah utama Pemerintah Daerah D.I Yogyakarta dalam merespons dampak pandemi COVID-19 ini diwujudkan melalui realokasi anggaran dengan prioritas pada sektor kesehatan, ekonomi, dan sosial. Anggaran untuk sektor kesehatan direalisasikan dalam bentuk pengadaan rapid test, pengadaan Alat Pelindung Diri (APD), dan insentif untuk para tenaga kesehatan yang menangani COVID-19. Untuk penanganan sosial, Pemerintah Daerah D.I Yogyakarta bersama Kementerian Sosial Republik Indonesia memberikan dana bantuan sosial sebesar Rp600.000 per Kepala Keluarga (KK) selama 3 bulan terhitung sejak bulan April, Mei, dan Juni 2020. Sektor ekonomi pun turut mendapat bantuan melalui insentif yang diberikan kepada perusahaan atau pengusaha dengan tujuan untuk meringankan tanggungan finansial, seperti penundaan cicilan, peniadaan denda bunga, dan lain-lain, serta memberikan insentif kepada pada pelaku pariwisata dan restoran.

Meski segala upaya telah dirasa menyeluruh, namun akan tetap ada berbagai pihak terdampak yang luput dari bantuan pemerintah. Agenda pemerintah yang begitu padat tentu membuat mereka memiliki keterbatasan kemampuan untuk menjangkau seluruh unsur masyarakat. Misalnya, penyaluran APD yang terlalu birokratis dan ketidakefektifan komunikasi antara rumah sakit rujukan dengan pemerintah menambah struggle tersendiri bagi tenaga medis dan tak jarang turut berdampak pada terhambatnya penyaluran APD oleh Pemerintah Daerah D.I Yogyakarta. Selain itu, fokus insentif yang hanya mencakup sektor bisnis dan pariwisata juga belum bisa dikatakan cukup karena pada realitanya, tidak hanya kedua sektor ekonomi tersebut saja yang terdampak. Pemberlakuan Pembatasan Sosial Berskala Besar (PSBB) pada awal merebaknya kasus COVID-19 di Yogyakarta yang berdampak pada tersendatnya roda perekonomian juga turut dirasakan oleh para pekerja kasar, petani, dan pedagang tradisional. Pihak-pihak itulah yang belum sepenuhnya mendapat perhatian dari pemerintah daerah.

Kondisi tersebutlah yang kemudian membuat pemuda di Yogyakarta tergerak untuk melakukan inisiasi. Mereka mengambil langkah yang tanggap, praktis, dan strategis untuk bersama-sama meringankan beban pihak-pihak yang rentan terhadap dampak COVID-19 ini. Dalam penelitian ini, konteks pihak yang rentan difokuskan pada tenaga medis dan pekerja informal di Yogyakarta. Untuk melihat peran pemuda secara lebih kontekstual dan menyeluruh, peneliti menemui beberapa perwakilan dari komunitas pemuda, yaitu Stucash dan Lakoni. Melalui berbagai gerakan yang diinisiasi, kedua komunitas pemuda ini mampu mengambil peran signifikan dalam penanganan bencana COVID-19 di D.I Yogyakarta. Peneliti juga menemukan adanya pendekatan-pendekatan yang unik khas net generation dalam upaya problem-solving yang dilakukan kedua komunitas ini.

Pertama, Stucash (Student Care and Share) merupakan lembaga sosial dan kepemimpinan yang berkonsentrasi pada pemberdayaan pemuda, khususnya pelajar. Komunitas ini diinisiasi pada tahun 2016 oleh beberapa pelajar SMA di kota Yogyakarta. Kemudian, Stucash melebarkan sayapnya dengan merekrut anggota komunitas yang seluruhnya merupakan pelajar tingkat sekolah menengah atas di Kota Yogyakarta. Sejak awal kemunculannya, komunitas ini konsisten memfokuskan diri sebagai komunitas kemanusiaan yang mempelopori aksi-aksi charity. Namun, seiring perkembangannya, komunitas ini juga berkembang menjadi wadah edukatif bagi para anggotanya dengan mengadakan berbagai kegiatan yang sifatnya skill-upgrading.

Lebih lanjut lagi, Stucash berkontribusi dalam penanganan COVID-19 di DIY dalam bentuk penggalangan dana secara terintegrasi yang kemudian hasilnya disalurkan dalam bentuk pengadaan APD untuk tenaga kesehatan di 25 fasilitas kesehatan di D.I Yogyakarta, baik rumah sakit rujukan maupun puskesmas. Integrasi aksi yang dilakukan Stucash ini memiliki kekuatan tersendiri sehingga mampu menggerakkan kalangan pelajar sekolah menengah atas hingga melibatkan mahasiswa dari berbagai sekolah dan universitas di D.I Yogyakarta.

Di tengah upaya pemerintah yang masih belum mampu menyelesaikan krisis di masyarakat yang diakibatkan oleh COVID-19 ini, kemunculan Stucash justru bisa dipandang sebagai gerakan alternatif yang turut 


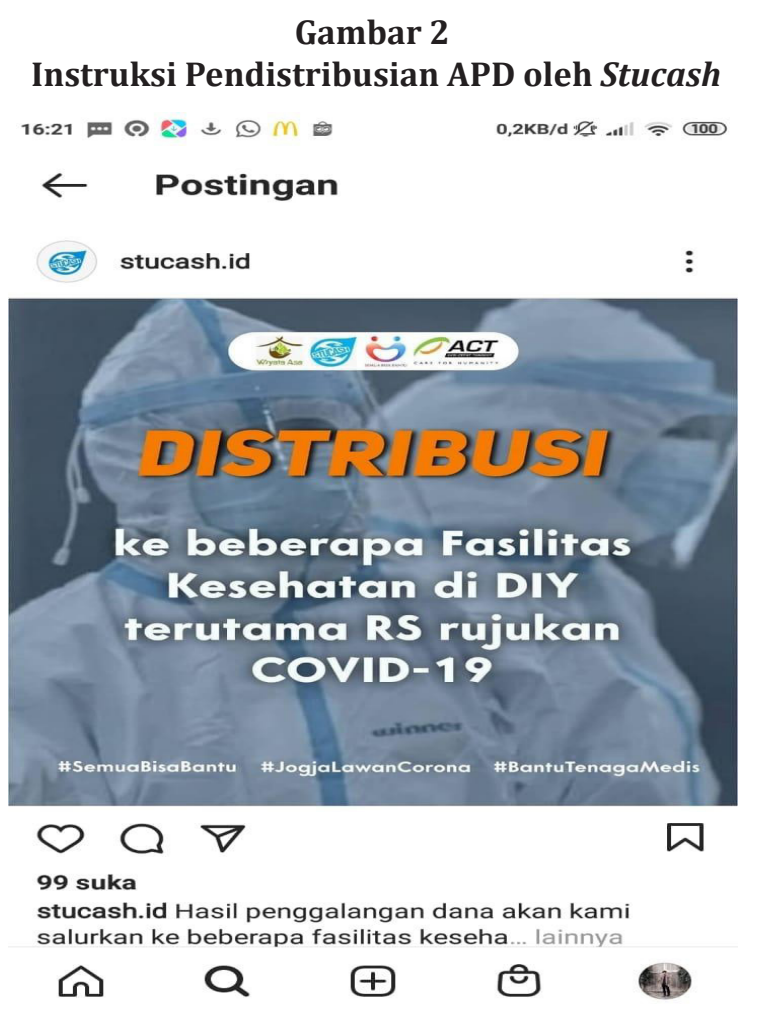

Sumber: Akun Instagram Stucash.id, 2020

berkontribusi secara signifikan. Hal tersebut dilihat dari bagaimana gerakan Stucash yang mampu memobilisasi massa yang cukup masif. Dengan cara memanfaatkan relasi volunteer yang merupakan pelajar SMA dan sederajat di Kota Yogyakarta, gerakan ini mendapat respons yang baik dari kalangan tersebut sehingga memberikan kemudahan untuk proses mobilisasinya sendiri. Tidak sampai di situ, penggalangan dana yang diinisiasi oleh Stucash juga turut menggandeng kalangan mahasiswa dari berbagai universitas di D.I Yogyakarta. Tercatat sebanyak tujuh organisasi BEM/LEM yang turut berkolaborasi dalam gerakan ini, yaitu BEM KM UGM, BEM KM UNY, BEM UPN, LEM UII, BEM UIN, BEM UMY, BEM Poltekkes Kemenkes, dan himpunan mahasiswa dari berbagai universitas di Yogyakarta.

Gerakan yang diinisiasi oleh Stucash ini juga dilakukan secara sistematis dan bersifat tepat sasaran. Sistematis dalam hal ini dilihat dari proses yang dilakukan oleh Stucash dalam mempersiapkan gerakannya. Dalam pendistribusian APD dan bantuan logistik lain terhadap tenaga medis, Stucash melakukan pendataan dan survei terhadap rumah sakit yang bersangkutan. Tidak hanya melalui pendataan mandiri, tetapi juga verifikasi dengan melibatkan himpunan mahasiswa farmasi dari Universitas Gadjah Mada yang menjembatani komunitas dengan rumah sakit terkait. Adanya pendataan dan verifikasi tersebut membuat komunitas memiliki pengetahuan yang akurat untuk mendistribusikan APD secara tepat sasaran.

Dari model integrating Community-based Disaster Management (ICBDM) yang dipaparkan oleh Chen \& Chan dalam Patterson et al. (2010: 132), Stucash memperkuat landasan aksinya dengan mengimplementasikan beberapa tahapan, yaitu initiation, assessment, dan planning. Sebagai komunitas yang telah cukup banyak menginisiasi aksi penggalangan dana, aksi "Jogja Lawan Corona" yang dipelopori oleh Stucash ini melalui tahap initiation dengan melakukan improvement dari pengalaman sebelumnya dalam menghadapi krisis akibat bencana. Jika pada aksi sebelumnya dilakukan secara luring dengan strategi turun ke jalan, aksi kali ini dilakukan secara terintegrasi melalui platform daring, seperti media sosial dan aplikasi dompet digital. Target volunteer pun tidak hanya menjangkau kalangan pelajar, tetapi juga mahasiswa. Dengan demikian, aksi "Jogja Lawan Corona" ini memiliki jangkauan yang lebih luas dan kohesivitas yang lebih kuat lagi.

Seperti yang telah dipaparkan sebelumnya, Stucash melakukan pendataan dan survei pada fasilitas kesehatan terkait sebagai pertimbangan untuk mendistribusikan APD supaya tepat sasaran. Aktivitas pendataan dan survei juga turut disoroti dalam model ICBDM dan diklasifikasikan pada tahap assessment. Tahap ini penting dilakukan oleh suatu komunitas yang hendak terlibat dalam penanganan krisis akibat bencana untuk memahami tingkat bahaya bencana dan kerentanan segmen masyarakat yang disasar. Selanjutnya, sebelum turun ke lapangan melakukan aksi, komunitas perlu melalui tahap planning. Pada tahap ini, komunitas mulai mengembangkan solusi dan strategi seiring dengan pemahaman mereka dalam penanganan bencana pandemi. Dalam konteks Stucash, tahap planning diimplementasikan melalui strategi pemanfaatan media sosial Instagram sebagai basis dalam menjangkau volunteer, memperluas relasi untuk kolaborasi, hingga akhirnya mampu berkontribusi dalam bentuk pengadaan dan distribusi APD secara maksimal untuk 25 fasilitas kesehatan di DIY.

Komunitas selanjutnya yang turut menjadi pembahasan pada tulisan ini adalah Lakoni. 
Miftah Awalurrizqi, Agresti Retno Sumantiyasmi, Atikah Azzahidah - Kolaborasi Komunitas Stucash dan Lakoni dalam Penanganan Dampak Sosial-Ekonomi Pandemi COVID-19

Lakoni merupakan komunitas pemuda berbasis di Yogyakarta yang memiliki fokus utama menjadi platform apresiasi seni, namun sekaligus menginisiasi untuk berbagai kegiatan berbagi dan menginspirasi. Komunitas ini terbentuk atas dasar keprihatinan anggotanya terhadap nasib masyarakat marginal yang bekerja sebagai pekerja informal. Kalangan masyarakat tersebut seringkali kurang mendapatkan perhatian dari pemerintah daerah, namun kelangsungan hidupnya terancam akibat dampak COVID-19. Selain bertujuan untuk membantu sesama, komunitas ini juga mewadahi generasi muda dalam berkarya melalui seni rupa.

Meskipun baruterbentuksetelahmerebaknya COVID-19 di Yogyakarta, namun komunitas ini cukup progresif dalam menginisiasi berbagai gerakan. Tercatat hingga September 2020, sudah terdapat empat aksi yang dilakukan. Mengusung tajuk Aksi Lakoni, komunitas ini mengawali gerakannya dengan membuka donasi melalui pembelian produk Seni Lakoni. Produk tersebut dijual dengan harga yang sama dengan harga pembuatan, kemudian pembeli bebas menambah jumlah donasi yang ingin diberikan sehingga tidak membebani pembeli dengan adanya minimal donasi. Pada Aksi Lakoni \#1, komunitas ini menyasar pada pedagang tradisional di Pasar Kranggan, Yogyakarta. Kontribusi yang dilakukan adalah dengan mendistribusikan hand sanitizer yang dibersamai oleh edukasi mengenai COVID-19 dan cara pencegahannya. Selanjutnya pada Aksi Lakoni \#2 dan \#3, komunitas ini menarget pada pekerja kasar, seperti tukang becak, pemulung, pengemudi ojek online, dan tukang parkir dengan membagikan 300 paket sembako. Terakhir, pada Aksi Lakoni \#4 yang juga berkolaborasi dengan Public Action UGM dilaksanakan dengan membagikan paket sembako kepada pekerja informal dan pelaku wisata di Tebing Breksi, Yogyakarta.

Kemunculan aksi Lakoni ini menjawab salah satu kelemahan dari penanganan krisis akibat bencana yang bersifat state-center, yaitu ketidakmampuan pemerintah dalam mengetahui kondisi masyarakat yang sesungguhnya. Hal tersebut disebabkan oleh keterbatasan "jarak pandang" pemerintah yang tidak mampu menjangkau seluruh kalangan masyarakat. Oleh sebab itu, adanya gerakan dari komunitas pemuda yang berbasis civil society ini sangat dibutuhkan mengingat kemampuannya dalam mengetahui kondisi masyarakat di sekitarnya,

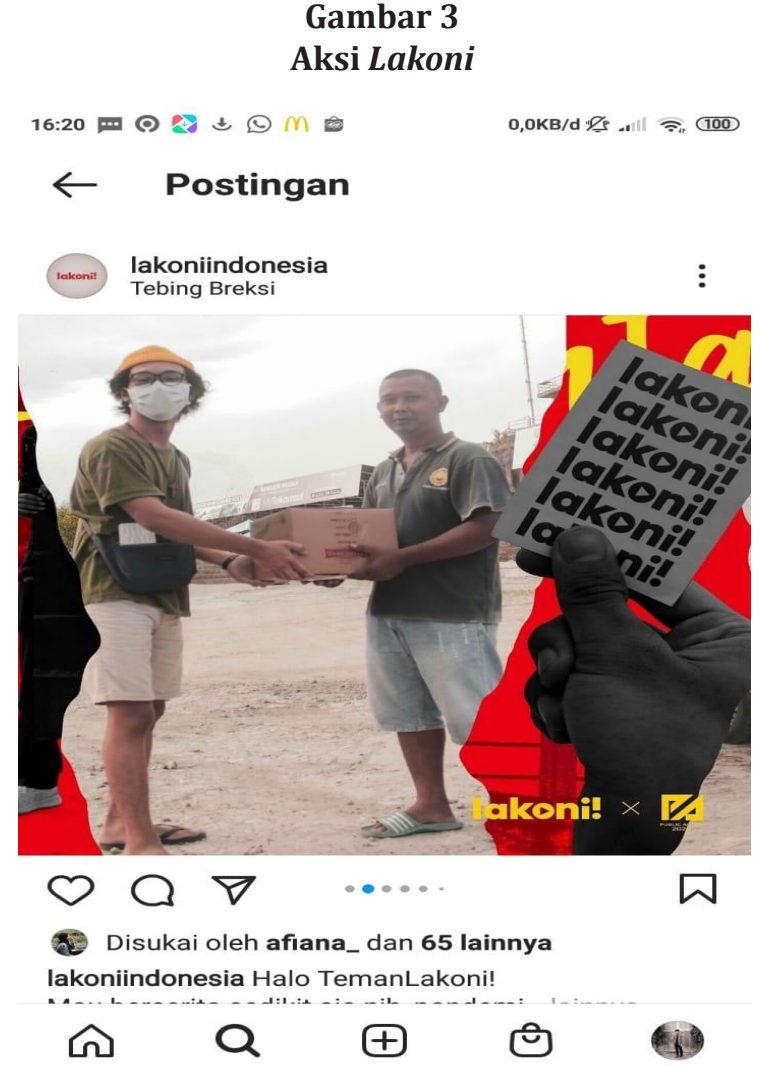

Sumber: Akun Instagram Lakoni Indonesia, 2020

termasuk kebutuhan dan kerentanan yang dimiliki. Konsep ini terlihat dalam gerakan yang dilakukan oleh komunitas Lakoni.

Hasil wawancara mendalam peneliti dengan perwakilan komunitas juga menunjukkan bahwa setiap gerakan yang dilakukan selalu berangkat dari realita yang terjadi di masyarakat. Temuan ini menandakan bahwa Lakoni sebagai komunitas pemuda mampu berperan sebagai representasi suara dan pikiran dari masyarakat sekitar sehingga menjadi pihak yang paham dengan kondisi lingkungan sekitarnya. Lakoni menentukan kalangan yang menjadi sasaran pendistribusian bantuan berdasarkan observasi langsung yang dilakukan oleh anggota komunitas Lakoni di lingkungan sekitarnya. Misalnya, dengan mengunjungi pasar tradisional untuk mengetahui sejauh mana pedagang tradisional memiliki literasi yang cukup dalam merespons pandemi ini. Dengan demikian, komunitas juga dianggap sebagai unsur masyarakat yang mampu menentukan gagasan yang tepat untuk mengatasi kerentanan pada masyarakat sekitarnya. Bentuk pendekatan komunitas yang seperti ini membuat komunitas menjadi lebih tanggap dalam merespon kebutuhan masyarakat sekitar. 
Bentuk manajemen bencana yang bersifat kolaborasi dengan civil society juga meyakini bahwa tidak ada satu pihak pun yang memiliki pengetahuan atau kapasitas yang cukup untuk mengatasi masalah yang begitu kompleks akibat bencana (Schwartz dan Yen, 2016: 127). Dalam konteks gerakan Lakoni, konsep ini diwujudkan dalam kolaborasi Lakoni dengan berbagai komunitas lain, seperti Sehat untuk Bekerja dan AMSA (Asian Medical Students' Association) UGM. Selain membantu proses pendistribusian logistik, kedua komunitas tersebut juga memberi gagasan kepada Lakoni terkait cara edukasi yang tepat dalam mencegah penularan COVID-19. Sesuai dengan konsep yang telah disebutkan sebelumnya, kolaborasi tersebut dilatarbelakangi oleh ketidakcukupan kapasitas masing-masing komunitas untuk bergerak sendiri. Lakoni yang memiliki latar belakang seni dan sosial kurang memiliki kapasitas di bidang kesehatan untuk mengedukasi terkait COVID-19 kemudian menggandeng Sehat untuk Bekerja dan AMSA UGM sebagai komunitas yang lebih fokus pada isu-isu kesehatan.

Hal menarik yang bisa dilihat dari kolaborasi Lakoni dengan kedua komunitas tersebut adalah adanya inklusivitas kolaborasi. Inklusivitas ini memungkinkan komunitas dengan perbedaan latar belakang yang cukup signifikan untuk saling bekerja sama atas dasar kesamaan visi yang dimiliki. Bentuk kerja sama antara Lakoni, Sehat untuk Bekerja, dan AMSA UGM yang menghasilkan output berupa edukasi implementatif terkait pencegahan COVID-19 kepada pedagang tradisional sesuai dengan pernyataan dari Marston et al. (2020: 1676) bahwa kolaborasi dengan komunitas akan lebih berpotensi untuk menemukan solusi inovatif yang sesuai dengan kebutuhan populasi.

\section{Komunitas Pemuda sebagai Bentuk Gerakan Sosial Tanggap Bencana}

Seperti yang telah dipaparkan sebelumnya, gerakan sosial merupakan bentuk dari tindakan kolektif yang dilakukan oleh sekelompok orang yang berkumpul di tempat yang mapan untuk mencapai tujuan bersama (Suharko, 2006; Sukmana, 2016). Dalam konteks ini, komunitas Stucash dan Lakoni, menjadi dua komunitas yang mewadahi masyarakat khususnya pemuda untuk melakukan gerakan sosial berupa penanggulangan pandemi COVID-19. Untuk dapat bergerak, gerakan sosial tentu membutuhkan sumber daya yang kemudian dapat dimobilisasi untuk mencapai tujuannya. Dalam hal ini, akan digunakan perspektif mobilisasi sumber daya untuk menelaah komunitas sebagai gerakan sosial dan kaitannya dengan sumber daya yang dimiliki. Perspektif mobilisasi sumber daya ini melihat gerakan sosial sebagai suatu tindakan yang diinisiasi oleh organisasi atau komunitas yang terstruktur dan menggerakkan sumber daya yang ada untuk melakukan tindakan kolektif (Manalu, 2007: 31-32). Melalui perspektif ini, kita melihat Stucash dan Lakoni menggunakan instrumeninstrumen tertentu untuk mengumpulkan, mengorganisir, dan menggerakkan sumberdaya demi tercapainya tujuan dari gerakan sosial tersebut.

Kolaborasi yang dilakukan oleh Stucash dengan pelajar dan mahasiswa, serta kolaborasi Lakoni dengan Sehat untuk Bekerja dan AMSA UGM kemudian dianalisis menggunakan teori struktur mobilisasi sumber daya. Dalam menanggulangi bencana pandemi, kelompokkelompok gerakan sosial ini membangun kekerabatan, baik antar anggota maupun antarkelompok. Sumber daya yang dimiliki adalah berupa partisipan yang datang dari anggota mereka sendiri dan relasi kerja sama dengan pihak-pihak lainnya. Relasi tersebut kemudian dilihat sebagai tindak lanjut upaya masing-masing kelompok untuk menciptakan penanganan COVID-19 yang fokus, cepat, dan sigap terhadap kalangan masyarakat yang dituju. Jika dikaitkan dengan teori struktur mobilisasi sumber daya, artinya faktor pendukung dominan yang membentuk gerakan sosial yang diinisiasi oleh Stucash dan Lakoni adalah tersedianya kelompok masyarakat.

Apabila berkaca pada realita yang terjadi, sumber daya yang berupa ketersediaan kelompok masyarakat menjadi aspek yang memperkuat gerakan sosial ini sendiri. Semakin banyak kelompok masyarakat yang dilibatkan, maka isu yang dibawa pada gerakan sosial juga akan semakin naik ke permukaan dan akan mengarah pada tingginya kesadaran publik yang terbentuk. Kesadaran tersebut tentu akan diikuti oleh semakin banyaknya volunteer atau sukarelawan yang tergerak untuk berpartisipasi dalam gerakan tersebut. Selain itu, ketersediaan kelompok masyarakat juga akan menumbuhkan dukungan publik yang akan berdampak pada terbentuknya kepercayaan 
publik terhadap komunitas tersebut. Gerakan sosial dengan kepercayaan publik yang kuat menjadikan gerakan tersebut menjadi lebih memiliki pengaruh dan integritas sehingga bisa memaksimalkan peran di tengah lingkungan sekitarnya.

Selain tersedianya kelompok masyarakat, Stucash dan Lakoni sebagai komunitas yang beranggotakan pemuda atau net generation juga memanfaatkan sumber daya berupa literasi digital yang dimiliki oleh para anggotanya. Dalam gerakan sosial yang dilakukan, terlihat penggunaan media baru sebagai cara baru dalam mendukung sebuah gerakan sosial di masyarakat. Oleh karen dengan adanya pandemi ini membuat aktivitas tatap muka sangat dibatasi, maka komunitas Stucash dan Lakoni menjadikan media sosial sebagai simpul utama untuk memobilisasi gerakan sosial. Kedua komunitas tersebut memanfaatkan media baru untuk mendukung gerakan sosial dalam pengumpulan bantuan. Media sosial Instagram dalam hal ini dianggap memiliki kekuatan yang luar biasa untuk menggerakkan publik melalui aksi sosial.

Berdasarkan teori ketergantungan, Instagram dipilih oleh Stucash dan Lakoni karena memiliki daya yang kuat untuk mengumpulkan, mengorganisir, dan menggerakkan sumber daya. Selain untuk memobilisasi sumber daya, Stucash dan Lakoni menggunakan Instagram untuk penyebaran informasi dan edukasi kepada khalayak luas mengenai pandemi COVID-19, serta dampaknya terutama di bidang sosial dan ekonomi. Fenomena tersebut sesuai dengan model tindakan sosial oleh Renckstorf (McQuail \& Windahl, 1993) yang mengatakan bahwa kondisi lingkungan sosial mempengaruhi motif penggunaan media baru oleh seorang individu. Adanya sumber daya berupa ketersediaan masyarakat serta kapabilitasnya dalam mengakses teknologi internet menjadikan kedua komunitas ini mampu memenuhi aspek daya tahan (endurance). Sebagai sebuah gerakan sosial, aspek daya tahan memungkinkan komunitas untuk dapat melaksanakan aksi serta mencapai tujuannya secara maksimal dan berkelanjutan.

\section{Geliat Kolaborasi Pemuda dalam Media Baru}

Media sosial dan pemuda saat ini memiliki kaitan yang erat. Berdasarkan penelitian yang dilakukan oleh Napoleon Cat (2020), pengguna media sosial khususnya Instagram di Indonesia pada tahun 2020 didominasi oleh golongan usia produktif yaitu 18-34 tahun. Kondisi tersebut memunculkan pemahaman baru mengenai Generasi $\mathrm{C}$, sebuah klasifikasi generasi berdasarkan karakter. Generasi $\mathrm{C}$ berpusat pada empat aspek yaitu creation, curation, connection dan community.

Stucash dan Lakoni yang memiliki basis pemuda juga tidak terlepas dari pergerakan melalui media baru ini. Media baru memungkinkan Stucash dan Lakoni untuk menciptakan sesuatu, mengkurasi, terhubung dan membentuk komunitas. Stucash dan Lakoni menciptakan konten multimedia untuk memenuhi tujuan tertentu. Dalam praktiknya, Stucash dan Lakoni melakukan penggalangan dana untuk membantu korban terdampak COVID-19. Mereka menciptakan poster digital dan video yang menarik dan menyebarkannya melalui media sosial. Stucash dan Lakoni pun menjalankan praktik kurasi, koneksi dan komunitas. Mereka mampu melakukan seleksi informasi yang sesuai dengan nilai dan tujuan mereka, mengkomunikasikannya melalui koneksi yang dibentuk dan pada akhirnya menciptakan komunitas. Fischer, Bristor dan Gainer (1996) berpendapat bahwa komunitas internet membebaskan dan memberdayakan. Sedikitnya isyarat sosial di internet membuat orang-orang lebih terbuka dan ramah (Sproull dan Kiesler, 1991). Hal ini sejalan dengan nilai yang dipercaya Lakoni bahwa dengan menciptakan komunitas sendiri mereka bisa bergerak lebih bebas tanpa terikat kepentingan politik tertentu yang hanya akan membatasi aksi mereka.

Lakoni sendiri bekerja dengan termediasi oleh media sosial, baik secara internal maupun eksternal. Anggota inti Lakoni yang berasal dari berbagai universitas di Indonesia melakukan koordinasi di media sosial. Keberagaman yang dimiliki oleh mereka memperluas koneksi. Setiap anggota memiliki koneksi dan lingkup sosialnya masing-masing. Hal ini memudahkan Lakoni untuk menyebarkan informasi dan aksi. Selan itu, kolaborasi juga menjadi kunci dalam memperluas dampak dari gerakan sosial. Hal ini disadari oleh Stucash dan Lakoni. Dalam melakukan aksinya, Stucash dan Lakoni berkolaborasi melalui berbagai cara. Berbagai saluran dimanfaatkan untuk memperluas penyebaran informasi. Mereka juga 
berkolaborasi bersama key opinion leader di sosial media, seperti Alit Jabang Bayi dan Nada Syifa. Stucash dan Lakoni menyatakan bahwa media sosial cukup efektif untuk meningkatkan kesadaran masyarakat mengenai aksi mereka. Hal ini dibuktikan dengan pencapaian Lakoni yang melebihi target.

Kolaborasi jenis baru yang terbentuk karena media baru bukan berarti hanya memindahkan kerjasama (teamwork) ke dalam sebuah ruang daring, tetapi juga kerja-kerja individu yang bergerak lebih untuk memberi ruang bagi orang lain. Platform Instagram Stucash dan Lakoni dapat dianggap sebagai alat kolaborasi yang akan mempertemukan berbagai pengguna dengan nilai yang sama. Selain Instagram, Lakoni juga bergerak di Twitter khususnya pada utas-utas terkait. Lakoni memahami perbedaan karakter media baru antara Twitter dan Instagram sehingga dapat menggunakannya secara efektif. Melalui cara tersebut aksi mereka lebih banyak dikenal dan dukungan lebih banyak mengalir, tidak terbatas ruang dan waktu.

Selain dikenal sebagai generasi C, mereka juga dapat dikategorikan sebagai net generation yang memang terlahir secara alami sebagai kolaborator. Dalam bukunya yang berjudul "The NetGeneration", Don Tapscott(1997) menyatakan bahwa net generation merupakan kolaborator di setiap aspek dari kehidupan mereka. Sebagai aktivis sipil, mereka memanfaatkan karakteristik kolaboratif ini dengan percaya diri. Mereka memiliki keinginan untuk membantu dan berkat kehadiran internet, bentuk-bentuk kolaborasi yang dihasilkan semakin variatif baik secara kualitas maupun kuantitas. Stucash dan Lakoni percaya dalam masa pandemi, setiap aktor sosial harus terhubung dan membantu satu sama lain. Berbekal keresahan tersebut, muncul berbagai gerakan yang melibatkan media baru.

Net generation tumbuh lebih banyak bersama internet daripada televisi. Internet sendiri bersifat dua arah dan tidak terikat ruang dan waktu. Berbeda dengan televisi yang bersifat hierarkis dan merefleksikan nilai-nilai dari pemilik industri, media baru sangat bertolak belakang dengan logika media lama. Media baru seperti sosial media memberi kontrol kepada pengguna. Tidak ada ada hegemoni kekuasaan dari atas ke bawah (top to down). Hal ini berdampak banyak pada pertumbuhan net generation, termasuk bagaimana mereka melakukan gerakan sosial dengan cara-cara baru. Tapscott (1997) mengatakan bahwa pemuda menjadi ujung tombak bagi perubahan cara berkomunikasi di masyarakat. Karena keadaan pandemi yang tidak memungkinkan interaksi fisik terlalu banyak, Stucash dan Lakoni memaksimalkan fungsi dari media baru. Misalnya Stucash melakukan riset dan pendekatan kepada rumah sakit atau instansi kesehatan yang membutuhkan APD. Hal ini cukup memotong sistem konvensional sebelumnya yang birokratis dan memakan waktu.

Sikap kolaboratif yang dimiliki oleh pemuda erat kaitannya dengan karakteristik lain yaitu kebebasan, kustomisasi, pengawasan, integritas, kolaborasi, hiburan, kecepatan dan inovasi. Net generation menjunjung tinggi kebebasan, mereka memiliki kekuatan untuk memilih nilai yang ingin mereka percayai dan jalan yang ingin mereka tempuh. Mereka menyukai kustomisasi dan personalisasi. Dalam konteks ini, net generation menciptakan produk sesuai keinginan mereka. Stucash dan Lakoni memiliki cara masing-masing dalam berkontribusi di masyarakat. Tidak ada standar paten dan produk yang dihasilkan akan semakin beragam. Mereka percaya bahwa ada seribu cara yang bisa ditempuh untuk mencapai sebuah tujuan.

Kebebasan terbentuk karena karakter media sosial yang tidak mengenal ruang dan waktu. Hal tersebut memungkinkan pemuda untuk bergerak, terhubung dan berkolaborasi lebih luas. Koneksi ini berkaitan dengan rekomendasi dan pengaruh yang diberikan satu sama lain. Stucash dan Lakoni menyadari bahwa dengan menggandeng pihak-pihak berpengaruh di media baru, aksi yang mereka lakukan akan diketahui banyak orang dan berpotensi mendapat dukungan lebih besar. Stucash dan Lakoni secara tidak sadar membentuk jaringan pemuda di media sosial yang berpotensi membawa perubahan.

Berdasarkan teori ketergantungan media (media dependency), aktivitas yang dilakukan oleh Stucash dan Lakoni menunjukkan bagaimana media berfungsi sebagai sistem komunikasi utama khususnya dalam menjalankan proyek sosial saat pandemi. Media sosial sebagai media alternatif menjadi hal penting mengingat hampir sebagian besar komunikasi selama physical distancing dilakukan melalui media sosial. Apabila ditelaah lebih lanjut, ketergantungan muncul karena perubahan sosial akibat dampak pandemi. Selain itu, kemampuan masyarakat 
Miftah Awalurrizqi, Agresti Retno Sumantiyasmi, Atikah Azzahidah - Kolaborasi Komunitas Stucash dan Lakoni dalam Penanganan Dampak Sosial-Ekonomi Pandemi COVID-19

untuk mengakses media juga dipengaruhi oleh semakin mudahnya akses masyarakat terhadap media dan beragamnya pilihan media.

\section{Kesimpulan}

Pemuda memiliki peran penting dalam gerakan sosial, khususnya dalam manajemen bencana COVID-19. Pemuda yang bersentuhan langsung dengan masyarakat dan memahami kondisi lapangan berperan penting untuk melengkapi kinerja pemerintah. Sebagai organisasi sukarela, komunitas Stucash dan Lakoni menjadi contoh nyata bagaimana kontribusi pemuda dapat memberi pengaruh positif terhadap upaya penanganan COVID-19 di D.I Yogyakarta. Aktivitas ini mewujudkan peran pemuda sebagai agents of change. Meskipun gerakan ini diinisiasi secara mandiri tanpa adanya material reward, pemuda dalam komunitas Stucash dan Lakoni tetap memiliki tekad kuat untuk turut andil mengambil peran dalam penanganan krisis akibat COVID-19 di D.I Yogyakarta.

Komunitas pemuda yang akrab dengan teknologi digital dapat menjadi penggerak bagi masyarakat untuk bersikap lebih adaptif. Pemuda dapat memanfaatkan kemajuan teknologi dan informasi untuk menyebarkan kegiatan mereka melalui situs web dan media sosial, tidak hanya untuk dokumentasi tetapi juga untuk menarik minat komunitas lain dan meraih lebih banyak volunteer. Aktivitas yang dilakukan oleh Stucash dan Lakoni ini juga menunjukkan bahwa media digital memiliki peran yang cukup krusial dalam gerakan sosial saat ini, khususnya dalam kondisi pandemi.

Akhirnya, adanya pandemi COVID-19 ini bisa menjadi pembelajaran yang bernilai untuk pemerintah dan masyarakat untuk saling mengevaluasi dalam hal penanganan bencana pandemi. Kesadaran dan aksi sosial yang dibentuk atas dasar inisiatif dari masyarakat akan mampu bertahan lebih baik dan berkontribusi lebih maksimal daripada upaya yang hanya bersifat top-down dari pemerintah. Oleh karena itu, ke depannya, pemerintah perlu menciptakan lingkungan yang mendukung tumbuhnya inisiatif masyarakat sipil dan lebih melibatkan komunitas sipil dalam penanggulangan bencana, terutama pada masa pemulihan pasca bencana.

\section{Referensi}

Borzekowski, D. L. (2019). Constancy (the New Media " $\mathrm{C}$ ") and Future Generations. Health Education \& Behavior 2019, 46(2S), pp. 20S-29S.

Cho, Y. (2009). New Media Uses and Dependency Effect Model: Exploring The Relationship Between New Media Use Habit, Dependency Relation, and Possible Outcomes. Doctoral dissertation, The State University of New Jersey. Retrieved from https://doi.org/doi:107282/T3GB249B.

Effendi, D., Agustiyara., Putra, H. A. (2019). Natural Disasters Management and the Challenge of Governability in Indonesia. Indian Journal of Public Administration, 65(3), pp. 627-645.

Hossain, A. (2013). Community Participation in Disaster Management: Role of Social Work to Enhance Participation. Antrocom Online Journal of Anthropology, 9(1), pp. 159-171.

Lakoni. (2020). Dipetik 2021, dari https://www. instagram.com/p/CCV0L6dhyxa/

Leo, O. (2019). Pelajar Jogja Kumpulkan Rp 29 Juta Untuk Bantu Korban Banjir. Radar Jogja: https://radarjogja.jawapos. com/2019/04/05/pelajar-jogjakumpulkan-rp-29-juta-untuk-bantu-korbanbanjir/diakses pada 25 Agustus 2020.

Manalu, D. (2007). Gerakan Sosial dan Perubahan Kebijakan Publik (Kasus Perlawanan Masyarakat Batak vs PT. Inti Indorayon Utama, di Porsea, Sumatera Utara). Populasi, 18(1), pp. 31-32.

Marston, C., Renedo, A., Miles, S. (2020). Community Participation Is Crucial in A Pandemic. The Lancet, 395(10238), pp. 1676-1678

Moleong, L. 2007. Metodologi Penelitian Kualitatif. Bandung: Remaja Rosdakarya.

Pantau Perkembangan COVID-19 di Yogyakarta. (2020). Diakses pada Agustus 28, 2020, dari https://corona. jogjaprov. go. id/rilis/ berita

Patterson, O., Weil, F., Patel, K. (2010). The Role of Community in Disaster Response: Conceptual Models. Popul Res Policy Rev, 29 (2), pp. 127-141.

Rettie, R. (2002). Net Generation Culture. Kingston Business School. Journal of Electronic Commerce Research, 3(4), pp. 254-264 
Schwartz, J., Yen, M. Y. (2016). Toward A Collaborative Model of Pandemic Preparedness and Response: Taiwan's Changing Approach to Pandemics. Journal of Microbiology, Immunology and Infection, 50(2), pp. 125-132.

Shils, E. (1960). The Intellectuals in the Political Developments of the New State. World Politics, 12(3), pp. 329-368. doi: 10. 2307/2009395

Smit, B., Wandel, J. (2006). Adaptation, Adaptive Capacity and Vulnerability. Global Environmental Change- Human and Policy Dimensions, 16(3), pp. 282-292.

Soemardjan, S. (2009). Perubahan Sosial di Yogyakarta. Depok: Komunitas Bambu.
Stucash.id. (2020). Dipetik 2021, dari https:// www.instagram.com/p/B-j1J-5htNI/

Suharko. (2006). Gerakan Sosial Baru di Indonesia: Repertoar Gerakan Petani. Jurnal Ilmu Sosial dan Ilmu Politik ,10(1), pp. 1-34. Sukmana, O. (2016). Konsep dan Teori Gerakan Sosial. Malang: Intrans Publishing.

Tapscott, D. (1997). Growing Up Digital: The Rise of the Net Generation. New York: McGraw Hill.

Widhyharto, D. S., (2014). Kebangkitan Kaum Muda dan Media Baru. Jurnal Studi Pemuda, 2(2), pp.141-146 